\title{
PERSAINGAN ELIT BANGSAWAN DENGAN KELOMPOK TERDIDIK PADA MASA REVOLUSI DI SULAWESI SELATAN
}

\author{
Najamuddin \\ (Dosen Pendidikan Sejarah-FIS Universitas Negeri Makassar) \\ Email: naja64unm@yahoo.com
}

\begin{abstract}
ABSTRAK
Penelitian ini bertujuan untuk: (1) Mengetahui latar belakang munculnya elit bangsawan dan kelompok terdidik, (2) Mengungkapkan Konflik antara elit bangsawan dengan kelompok terdidik yang berimplikasi pada peran keduanya di Masa Revolusi di Sulawesi Selatan. Metode penelitian yang digunakan dalam penelitian ini adalah metode penelitian sejarah. Tahapan dalam penelitiannya yaitu pemilihan topik, mengumpulkan sumber, kritik sumber, interpretasi, dan historiografi. Hasil penelitian menunjukkan bahwa Stratifikasi sosial masyarakat Bugis-Makassar telah memberikan posisi istimewa terhadap kaum bangsawan sebagai elit strategis dari kelompok masyarakat lainnya dalam struktur sosial, dan sebagai pemimpin puncak dalam struktur politik atau struktur kekuasaan. Ketika elit terdidik tampil dalam Pergerakan Nasional di Sulawesi Selatan bersama elit bangsawan, politik kolonial Belanda berhasil mempolarisasi keduanya menjadi bagian yang terpisah menjadi konflik di awal kemerdekaan RI.
\end{abstract}

Kata Kunci: Elit Bangsawan, Kelompok Terdidik, dan Revolusi di Sulawesi Selatan

\begin{abstract}
This study aims to: (1) Knowing the background of aristocratic elite and educated group, (2) Disclose Conflicts between the aristocratic elite educated group that has implications for the role of both in the Revolution in South Sulawesi. The research method used on this research is history research method. Steps on this research are selecting topic, collecting sources, sources critism, interpreting, and historiography. The results showed that the social stratification of society BugisMakassar has given a privileged position against the nobility as a strategic elites of other communities in the social structure, and as a top leader in the political structure or structures of power. When the educated elite to appear in the National Movement in South Sulawesi together aristocratic elite, the Dutch managed to polarize politics both into separate parts into conflict at the beginning of independence
\end{abstract}

Keywords: Elite Noble, educated group, and Revolution in South Sulawesi 


\section{Pendahuluan}

Persiapan menjelang kemerdekaan RI di Sulawesi Selatan memperlihatkan jalinan kerjasama yang harmonis antara elit bangsawan dengan kelompok terdidik dari kalangan pergerakan nasional. Mereka bahu membahu menggelorakan semangat nasionalisme di kalangan pejuang kemerdekaan. Kesadaran akan pentingnya semangat nasionalisme dan persatuan demi mewujudkan negara yang merdeka memang sudah tertanam pada diri elit bangsawan maupun kelompok terdidik. Elit bangsawan yang memiliki wibawa di hadapan masyarakat mampu menggerakkan masyarakat untuk mempersiapkan kemerdekaan Indonesia. Sedangkan kelompok terdidik yang memiliki wawasan luas mampu memberikan pencerahan dan meyadarkan masyarakat untuk bersatu demi kemerdekaan Indonesia.

Namun, jalinan kerjasama antara elit bangsawan dengan kelompok terdidik akhirnya retak. Hal tersebut terjadi kaum terdidik dari kalangan pergerakan nasional merasa tersingkirkan karena tidak diikutsertakan wakilnya dalam menghadiri rapat Panitia Persiapan Kemerdekaan Indonesia di Jakarta. Dominasi elit bangsawan sebagai utusan wakil dari Sulawesi Selatan dalam rapat PPKI tersebut akhirnya menjadi pemicu awal dari konfik antara kaum terdidik dari kelompok pergerakan nasional dengan elit bangsawan. Kelompok terdidik menganggap bahwa utusan untuk rapat PPKI yang didominasi oleh elit bangsawan tersebut kurang adil. Situasi ini semakin lama semakin memanas sehingga menimbulkan perpecahan antara elit bangsawan dengan kelompok terdidik.

Dalam stratifikasi sosial masyarakat Bugis-Makassar, telah memberikan posisi istimewa terhadap kaum bangsawan sebagai elit strategis dari kelompok masyarakat lainnya. Masyarakat Bugis-Makassar sebagai pemimpin puncak dalam struktur sosial, politik, maupun kekuasaan. Stratifikasi masyarakat Bugis-Makassar yang dibagi berdasarkan kasta-kasta atau golongan-golongan tersebut dianggap suatu faktor penting yang menguasai atau mempengaruhi kehidupan sosial ekonomi dan religius masyarakat Sulawesi Selatan (Daeng Patunru, 1967: 145). Umumnya masyarakat Sulawesi Selatan terkenal sebagai masyarakat yang sangat ketat mempertahankan aturan pelapisan sosial ini. Bahkan di kalangan masyarakat terdapat anggapan bahwa mempertahankan pelapisan sosial merupakan syarat berjayanya suatu negeri (Mattulada, 1975: 324).

Kurun waktu antara tahun 1905 hingga 1910 merupakan periode ekspedisisi militer Hindia Belanda untuk menaklukkan kerajaan-kerajaan yang masih berdaulat di wilayah Sulawesi Selatan. Dalam periode pasifikasi inilah berlangsung perlawanan terakhir kerajaan-kerajaan Bugis-Makassar terhadap Belanda. Kekalahan kerajaankerajaan Bugis-Makassar serta ditandatanganinya Koorte Verklaring (perjanjian pendek), membuka lembaran baru dalam sejarah hubungan kerajaan-kerajaan BugisMakassar dengan pemerintah Hindia Belanda.

Takluknya kerajaan-kerajaan BugisMakassar tersebut sekaligus juga menandai dimulainya campur tangan Belanda yang makin jauh dalam lembaga pemerintahan daerah-daerah yang memiliki pemerintahan sendiri. Hal ini sekaligus menandai berlangsungnya dualisme dalam struktur pemerintahan kerajaan di Sulawesi Selatan: disatu pihak pejabat-pejabat adat dan agama yang berasal dari kelompok masyarakat setempat, dan pada pihak lain terdapat pejabat-pejabat pemerintah Hindia Belanda, yang bertugas untuk membantu dan mengawasi pejabat-pejabat adat dan agama (Hasan Walinono, 1979). Kelompok yang

Najamuddin, Persaingan Elit Bangsawan dengan Kelompok Terdidik pada Masa Revolusi di Sulawesi Selatan 
terakhir ini, terdiri dari kelompok bangsawan dan orang-orang Belanda.

Sejak itu pula muncullah suatu golongan elit baru di Sulawesi Selatan yang kekuasaan, kewenangan pengaruh, dan prestisenya bersumber dari nilai-nilai dan aturan-aturan lain yang berlaku pada wilayah yang lebih luas, melebihi batas fisik persekutuan adat tertentu. Nilai-nilai dan aturan-aturan itu pada mulanya berasal dari pemerintah Hindia Belanda, kemudian pemerintah pendudukan Jepang dan sejak kemerdekaan, hingga masa pemerintah Republik Indonesia.

Adapun yang dianggap dalam golongan elit baru tidak saja para pejabat Hindia Belanda, Jepang atau Republik Indonesia, tetapi juga berbagai orang lain yang bukan pejabat. Seperti; cendikiawan, pemimpin partai, pengusaha dan sebagainya. Karena walaupun mereka bukan pejabat pemerintah, namun sumber kekuasaan, kewenangan, pengaruh dan prestisenya bukan bersumber dari nilai-nilai dan aturanaturan Bugis-Makassar dan Islam, tetapi dari nilai-nilai dan aturan baru yang berbeda dari nilai-nilai dan aturan-aturan adat BugisMakassar dan Islam.

Golongan elit bangsawan dan kelompok terdidik sama-sama memiliki peran yang besar dalam memperjuangkan kemerdekaan Indonesia. Keduanya memiliki pengaruh dan reputasi di kalangan masyarakat Sulawesi Selatan. Pada mulanya, kedua kelompok ini bersatu-padu dalam menggalang kekuatan demi persatuan Indonesia. Namun, keadaan memanas ketika Nadjamuddin Daeng Malewa berseteru dengan Ratulangi yang menjadi wakil ke Jakarta dalam rapat PPKI. Keadaan ini kian memanas dan dimanfaatkan oleh pemerintah Hindia Belanda untuk melemahkan integritas mereka.

\section{Hasil Penelitian dan Pembahasan}

\section{Posisi Elit Bangsawan}

Berkaitan dengan penempatan posisi bangsawan dalam stratifikasi sosial ini, dalam masyarakat Bugis-Makassar terdapat hubungan yang sangat kompleks antara individu satu dengan individu lainnya. Pada zaman dahulu hubungan-hubungan yang paling erat adalah hubungan antara bangsawan dan pengikut-pengikutnya. Misalnya dalam peperangan, seorang bangsawan bersama dengan pengikutpengikutnya merupakan satu kelompok siri' (secara bersama-sama membela siri'nya) melawan kelompok siri' yang lain yang juga terdiri dari bangsawan dan pengikutpengikutnya. Dalam hubungan ini, sama sekali tidak pernah terjadi bahwa orangorang dari lapisan bawah beberapa kelompok siri' bersatu untuk melawan bangsawannya (Errington, 1977: 61). Pola hubungan patron-klien antara yang memimpin dan yang dipimpin atau pelindung dengan yang dilindungi dalam Bugis-Makassar seperti di atas, terwujud dalam hubungan antara Ajjoareng dengan Joa atau Tunipinawang dengan Tumminawang atau antara KaraEng dengan Taunna (Mukhlis dan Robinson, 1985).

Hubungan antara pelindung dengan yang dilindungi bersifat sukarela namun tidak mudah terpisahkan. Diantara keduanya mempunyai hak-hak dan kewajiban masingmasing, mereka mempunyai hubungan timbal balik yang saling menguntungkan antara yang melindungi dan yang dilindungi (Mukhlis dan Robinson, 1985). Dalam hubungan yang lebih sempit, yaitu hubungan antara bangsawan tertentu sebagai pemimpin (ajjoareng) dengan para pengikutnya (joa), kewajiban bangsawan untuk membantu dan memperhatikan kesejahteraan pengikutnya lebih menonjol lagi. Kewajiban ini mencerminkan rasa solidaritas, rasa setia kawan antara pemimpin dan pengikutnya. Kewajiban ini juga merupakan imbalan

Najamuddin, Persaingan Elit Bangsawan dengan Kelompok Terdidik pada Masa Revolusi di Sulawesi Selatan 
terhadap hak bangsawan untuk menerima kesetiaan dan loyalitas para pengikutnya (Hasan Walinono, 1979: 93).

Pola hubungan atas dasar klasifikasi sosial seperti di atas, telah mendudukkan bangsawan pada kelompok elit yang sangat terhormat di Sulawesi Selatan. Walaupun hubungan antara bangsawan dengan rakyatnya sangat ketat dan bersifat feodal, namun hubungan keduanya diwarnai dengan sikap demokratis. Kenyataan ini diperkuat dengan terikatnya raja dan kelompok bangsawan pada suatu Governmental Contract (Mattulada, 1975: 383) atau perjanjian pemerintahan dengan rakyat atau masyarakat yang dipimpinnya. Kemudian dalam sistem sosial, tercipta pula semacam kontrak sosial (Hamid Abdullah, 1985: 84) antara penguasa yang pada umumnya terdiri dari bangsawan dengan masyarakat. Perjanjian pemerintahan ataupun kontrak sosial ini telah tercipta sejak masyarakat Bugis-Makassar membentuk sistem ketatanegaraannya di masa pemerintahan Tomanurung.

Dalam perjanjian tersebut, telah diatur dan ditetapkan tentang batas-batas kekuasaan kelompok penguasa di masyarakat atau terhadap rakyat yang dipimpinnya. Seperti hak raja atau penguasa untuk memberikan perlindungan kepada hak milik rakyatnya, melindungi rakyatnya dari perbuatan yang bersifat sewenang-wenang, berlaku adil terhadap rakyat yang dipimpinnya, tidak membedakan kelompokkelompok yang hidup dan berada di bawah kekuasaannya, menghormati hak suara rakyatnya. Raja dan penguasa juga tunduk dan patuh serta melindungi adat yang hidup di masyarakat dan sebagainya.

Kontrak sosial yang mendudukkan hubungan yang "seimbang" antara raja (bangsawan) dengan rakyatnya diimplementasikan lewat sanksi hukum bagi pelanggar kesepakatan. Apabila ternyata di kemudian hari ada seorang raja atau penguasa yang melakukan penyelewengan atau telah melanggar kesepakatan yang telah menjadi undangundang di masyarakat, maka rakyat mempunyai hak untuk melakukan protes atau reaksi terhadap raja dan penguasanya. Demikian juga sebaliknya, bila terdapat seorang rakyat atau kelompok rakyat yang terbukti menghina, melakukan pembangkangan, dan tidak patuh pada perintah rajanya dalam ukuran yang tidak keluar dari kesepakatan, maka rajanya dapat menghukum rakyatnya sesuai dengan hak yang diberikan kepadanya (Mattulada, 1975: 383). Dengan demikian, walaupun raja atau kelompok bangsawan memiliki kedudukan sebagai elit strategis di masyarakat dalam struktur sosial dan sebagai pemimpin puncak dalam struktur politik atau kekuasaan, kelompok ini tidaklah memiliki kekuasaan yang bersifat mutlak karena dikontrol oleh norma dan kontrak sosial yang telah disepakati bersama rakyat sebelumnya.

Ikatan hubungan historis di atas terus dijalin oleh bangsawan dan rakyat Sulawesi Selatan pada umumnya. Baik berkedudukan sebagai raja, maupun masyarakat bangsawan tidak pernah surut melindungi rakyatnya. Posisi bangsawan yang tetap konsekuen ini, menjadikan dirinya sebagai elit "terdepan" dalam masyarakat Bugis-Makassar. Raja meskipun telah kehilangan kekuasaan politiknya secara resmi dengan rakyatnya ketika dikuasai oleh Belanda pada abad ke20 bahagian pertama, dan kekuasaannya telah dikontrol oleh Residen dan Kontroler, tetapi tingkah laku sosial dan kebijakannya di masyarakat tetap berada dalam siklus adat yang masih hidup dan berakar dimasyarakat, demikian juga sikap rakyat terhadap rajanya (Hamid Abdullah, 1990: 35).

Kenyataan ini diperlihatkan oleh perlawanan Sultan Hasanuddin 1666-1669 yang mempertahankan hegemoni Kerajaan

Najamuddin, Persaingan Elit Bangsawan dengan Kelompok Terdidik pada Masa Revolusi di Sulawesi Selatan 
Gowa dari pengaruh pemerintah kolonial Belanda. Seperti halnya Arung Palakka yang secara kultural dapat menegakkan siri'nya dan rakyatnya, demikian juga perlawanan rakyat di bawah pimpinan raja dan bangsawan di berbagai kerajaan-kerajaan seperti; Luwu, Mandar, Wajo, Soppeng, Tanete, Barru, Suppa dan Sidenreng, dan lain-lain.

Pada masa Revolusi, keterlibatan raja dan bangsawan untuk tetap berdiri di belakang Republik melawan penjajahan Belanda membuktikan betapa setianya kaum bangsawan terhadap rakyatnya. Demikian juga rakyat Sulawesi Selatan senantiasa setia mendampingi bangsawan dalam melawan Belanda. Kenyataan tersebut membuktikan, bahwa bangsawan tidak pernah mengingkari norma dan kontrak sosial yang pernah disepakati bersama rakyat, dia tetap berdiri sebagai pelindung dari rakyat yang membutuhkan perlindungannya. Disinilah letak, mengapa posisi raja ataupun bangsawan tidak pernah luntur di mata rakyat Sulawesi Selatan, sehingga tetap mendapat tempat di hati rakyat pada masa Revolusi.

\section{Kelompok Terdidik}

Munculnya elit baru pada permulaan abad ini di Sulawesi Selatan, untuk pertama kalinya dimulai dengan ditempatkannya pejabat-pejabat pemerintah Hindia Belanda yang jumlahnya masih sangat terbatas. Tetapi bersamaan dengan makin jauhnya campur tangan Belanda dalam administrasi pemerintahan di Sulawesi Selatan, makin bertambah pula jumlah anggota golongan elit baru di Sulawesi Selatan. Jumlah elit baru ini makin bertambah seiring dengan berkembangnya pendidikan di Sulawesi Selatan.

Kepentingan pemerintah Hindia Belanda memperlancar administrasi wilayah kolonialnya di Sulawesi Selatan, mengharuskan memperbaharui Perjanjian Bungaya untuk kedua kalinya pada tanggal 26 Oktober 1894 yang ditanda-tangani oleh Gubernur Djenderal C.H.W. van Der Wijk dengan Raja Gowa Sultan Muhammad Idris bersama dewan Bate-Salapanga. Di antara isi perjanjian tersebut adalah diharuskannya memajukan pendidikan umum atau rakyat atau voolks onderwijs yang mengambil-alih sekolah yang didirikan B.F. Matthes Kweeksschool (Daeng Patunru, 1967: 105112). Dengan demikian, keterlibatan Raja Gowa memajukan pendidikan yang disepakati dengan pemerintah Hindia Belanda, menjadi pertanda dibolehkannya penduduk masyarakat biasa di lingkungan Kerajaan Gowa memasuki lembaga pendidikan itu.

Salah satu sekolah yang banyak memberikan sumbangan bagi pembentukan semangat nasionalis di Sulawesi Selatan adalah Perguruan Taman Siswa yang didirikan oleh Mr. Sunaryo pada tahun 1936. Melalui Perguruan Taman Siswa inilah banyak bermunculan tokoh-tokoh nasional asal Sulawesi Selatan, diantaranya; Manai Sophian, Wahab Tarru, H. Azikin, Saelan, dan lain-lain. Masuknya pemerintah militer Jepang tahun 1942 tidak merubah sistem pendidikan yang ada seperti pada masa pemerintahan Hindia Belanda, tetapi tetap dilanjutkan dan hanya nama sekolah yang berubah disesuaikan dengan bahasa Jepang.

Dalam bidang budaya, Jepang sedikit mengembangkan. Di bidang linguistik misalnya, Jepang dibandingkan dengan yang pernah dilakukan Belanda, telah memberikan stimulasi untuk penggunaan dan pengembangan bahasa nasional Indonesia, demikian juga pengibaran bendera Indonesia berdampingan dengan bendera kebangsaan Jepang. Upaya untuk membangkitkan penduduk pedesaan agar terlibat dalam perang mereka, mengakibatkan propaganda yang dilakukan

Najamuddin, Persaingan Elit Bangsawan dengan Kelompok Terdidik pada Masa Revolusi di Sulawesi Selatan 
mengharuskannya demikian (W.F.Wertheim, 1999: 263).

Sementara itu, peranan Perguruan Muhammadiyah dalam memajukan pendidikan dengan mendirikan sekolahsekolah di tiap daerah, dapat menyeimbangi peran para zending dan pihak pemerintah Hindia Belanda (Sarita Pawiloy, 1981: 9798) yang bertujuan untuk menampung dan mempersatukan para pemuda melawan penjajahan, dimana pihak pemerintah Belanda juga kurang memperhatikan pendidikan Islam pada masa itu. Pada tanggal 8 Oktober 1945 para tokoh pergerakan nasional di Makassar, seperti; Gubernur Sulawesi Dr. G.S.S.J. Ratulangi, Lanto Daeng Pasewang, Mr. Zainal Abidin, Suwarno dan Malajong Daeng Liwang mendirikan sebuah Perguruan Nasional yang bertujuan memupuk semangat kebangsaan dan menghasilkan kader bangsa bagi pemuda -pemuda yang ada di Makassar. Ide-ide nasional Republiken dipompakan kepada anak didik melalui pelajaran sejarah dan bahasa Indonesia. Dari sekolah inilah muncul pemuda militan seperti; Wolter Mongisidi, Rivai Paerai dan sejumlah tokoh pejuang yang menentang kekuasaan NICA-Belanda di Sulawesi Selatan (Mukhlis, 1995, Sarita Pawiloy, 1981: 97-98). Pada masa pemerintahan NIT keadaan pendidikan telah dapat diperbaiki, sedikitnya sebagai langkah pertama untuk membenahi dunia pendidikan yang tersendat akibat perang. Pada masa Pemerintahan Negara Indonesia Timur telah dibuka sebanyak 6 buah sekolah guru B (SGB) yang mempunyai kapasitas murid kurang lebih 400 orang. Selain itu juga terdapat 23 buah $O . V . V . O$ (= sekolah guru) dengan kapasitas murid kurang lebih 2000 orang. (Kementerian Penerangan RI, 1953: 498499).

Sementara itu perkembangan pendidikan formal baik pada masa sebelum perang dunia kedua, maupun pada masa pemerintahan Negara Indonesia Timur menunjukkan peningkatan yang berarti ditandai dengan berdirinya sebanyak 1316 Sekolah Rakyat, 40 buah sekolah menengah dan 1 buah sekolah tinggi atau Fakultas Ilmu Ekonomi (ARNAS Perwakilan Makassar-Arsip Pribadi Saleh Lahade).

Perkembangan keadaan pendidikan di Sulawesi Selatan baik pada masa sebelum perang maupun sejak Revolusi Kemerdekaan atau masa pemerintahan NIT belum banyak mengalami perubahan, keadaan ini berlanjut hingga Sulawesi Selatan memasuki kawasan pergolakan DI/TII dan Peristiwa Andi Aziz (Anhar Gonggong, 1992, 35-40). Terbatasnya memperoleh peluang pendidikaan, menyebabkan sebagian pemuda menempuh sekolah lanjutan di Pulau Jawa. Kelompok inilah yang kemudian banyak menjadi kelompok elit nasional yang sedang berkembang atau menjadi kaum pergerakan. Di Sulawesi Selatan sendiri, walaupun kemajuan pendidikan termasuk dalam kategori terbatas, tetapi tidak dapat dipungkiri bahwa tidak sedikit elit terdidik yang dihasilkan dari perkembangan pendidikan ini kemudian menjadi tenaga penggerak dari lahirnya nasionalisme di daerah tersebut.

Dengan demikian, dari berbagai sekolah yang didirikan baik pada masa awal masuknya pemerintah kolonial Belanda, pada masa pendudukan pemerintah militer Jepang, maupun menjelang proklamasi kemerdekaan dan sesudahnya, ternyata banyak membawa pengaruh bagi pertumbuhan organisasi pergerakan nasional. Pihak penjajah sebelumnya kurang menyadari bahwa lewat pendidikan rupanya orang-orang dapat tercerahkan, dan ini menjadi bumerang bagi pihak penjajah itu sendiri. Semangat nasionalisme rupanya tumbuh di sekolah-sekolah seperti Perguruan Taman Siswa, Perguruan Nasional, juga 
perguruan-perguruan Islam yang memang anti Barat. Sumbangan sekolah yang didirikan para Zendingpun tidak terkecuali dari pemupukan tumbuhnya semangat nasionalisme di kalangan nasionalis yang berada di Makassar.

\section{Konflik Antara Elit Bangsawan Dengan Kelompok Terdidik}

Makassar sebagai pusat kota Sulawesi Selatan, sejak abad ke-20 sudah menjadi titik centrum berlangsungnya proses komunikasi manusia dari berbagai asal di Indonesia. Menurut catatan dalam ensiklopedia tahun 1922 yang dikutip oleh Mukhlis Paeni et.al., penduduk kota Makassar pada tahun 1916 berjumlah lebih kurang 39.000 jiwa yang terbagi dalam berbagai jenis suku dan agama (Mukhlis, 1984: 63).

Dalam perkembangannya. Makassar sebagai ibukota NIT yang berpenduduk cam-puran dari berbagai ras atau etnis, dihuni oleh sejumlah kesatuan sosial pada masa itu. Secara horisontal ditandai dengan kenyataan adanya perbedaan suku bangsa dan masing-masing mempunyai identitas kebudayaannya sendiri. Demikian juga kepercayaan agama yang bermacam-macam. Struktur masyarakat ditandai oleh adanya perbedaan secara vertikal antara lapisan atas dan lapisan bawah yang cukup tajam, sedang struktur politik tradisional terdapat dari mulai anak suku (wanua) sampai tingkat kerajaan. Mobilisasi manusia antar daerah, antar pulau dan antar etnis tersebut membawa perubahan-perubahan besar pada perkembangan kota Makassar dalam kurun waktu tersebut.

Dalam bidang organisasi pergerakan, perkembangannya banyak diwarnai dengan keterlibatan orang-orang dari berbagai daerah dan etnis di luar daerah Sulawesi Selatan, termasuk di dalamnya orang-orang Sulawesi Selatan sendiri yang pernah mengenyam pendidikan lanjutan kemudian masuk membangun semangat nasionalisme di daerah kelahirannya. Kelompok inilah yang kemudian disebut sebagai elit terdidik. Pada masa pendudukan Jepang, perkembangan organisasi Pergerakan Nasional di Sulawesi Selatan yang digerakkan oleh berbagai etnis ini, mengalami banyak hambatan dibanding dengan yang terjadi di pulau Jawa. Hubungan dengan para tokoh pergerakan di Jakarta sangat lambat. Perkembangan politik ini berlangsung hingga menjelang Proklamasi Kemerdekaan 1945 (R.Z.Leirissa, 1975: 135).

Lemahnya organisasi Pergerakan Nasional di Sulawesi Selatan mendorong tokoh Pergerakan Nasional di pusat; Soekarno mengirim tokoh-tokoh pergerakan ke Makassar pada bulan Desember 1943 dengan tujuan untuk mengisi kekosongan pimpinan nasional serta lebih mempergiat gerakan nasional di Sulawesi Selatan dalam menyambut kemerdekaan (Anthony J.S.Reid, 1986: 61), diantara yang dikirim adalah; Dr.GSSJ. Ratulangi, Mr. Tadjuddin Noor dan J.D. Sijaranamual. Kemunculan tokoh-tokoh Pergerakan nasional di Sulawesi Selatan membawa dampak yang luas bagi perkembangan politik di daerah ini, terutama terbentuknya dua kekuatan yang saling bersaing dalam merebut posisi terdepan di gelanggang politik Sulawesi Selatan. Di satu sisi terdapat kelompok nasionalis dari kaum pergerakan dan kelompok bangsawan yang menyatakan dirinya berdiri di belakang RI dan menolak negara federal, disisi lain terdapat kelompok "nasionalis-lokal" yang terdiri dari elit bangsawan dan kaum pergerakan yang mendukung negara Federal sebagai satu-satunya jalan menuju pembentukan Republik Indonesia Serikat (RIS).

Sebelum tibanya tokoh-tokoh nasional tersebut di atas, di Sulawesi Selatan

Najamuddin, Persaingan Elit Bangsawan dengan Kelompok Terdidik pada Masa Revolusi di Sulawesi Selatan 
sudah muncul beberapa organisasi Pergerakan Nasional cabang dari organisasi pergerakan yang ada di Jawa, seperti; Muhammadiyah, Sarekat Islam, PNI, Partindo, Gerindo dan Parindra dengan tokoh seperti; Mr.Sunario, Iskaq Tjokroadisoerdjo A. Wahab Tarru, Achmad Siala, Ince Achmad Dahlan, Sikado Daeng Nai, Haji Muhammad Azikin, Saelan, Manai Sophian dan Nadjamuddin Daeng Malewa. Nadjamuddin Daeng Malewa adalah tokoh Parindra yang kemudian membentuk organisasi Pergerakan Nasional bercorak lokal bernama Partai Serikat Selebes. Menjelang masuknya Jepang, tokoh-tokoh nasional asal pusat ini kemudian meninggalkan Makassar.

Sebelum Dr. Ratulangi dan yang lainnya dikirim ke Makassar, Nadjamuddin Daeng Malewa sudah merupakan tokoh pergerakan nasional terkemuka di Sulawesi Selatan yang telah mengakar dikalangan rakyat (Manai Sopian, 1991: 25), dalam beberapa catatan tokoh ini jarang tertandingi oleh tokoh pergerakan lokal pada zamannya. Sejak kedatangan Dr. Ratulangi dan kawankawannya di Makassar, kelihatan ada suatu persaingan yang kemudian akan menjadi kendala besar bagi jalannya sejarah kemerdekaan di Makassar. Nadjamuddin Daeng Malewa beserta pemimpin-pemimpin lokal lainnya merasa dirinya tersingkirkan, apalagi Dr. Ratulangi semakin menonjol, baik di kalangan tokoh pergerakan lokal maupun di kalangan Bangsawan yang kemudian banyak berpengaruh pada kelanjutan karier politiknya di Sulawesi Selatan.

Sebelum Proklamasi Kemerdekaan Dr. Ratulangi berusaha menggalang semua unsur kekuatan di Sulawesi Selatan. Sebagai langkah awal maka, Dr. Ratulangi mendekati pihak bangsawan yang sangat berpengaruh di daerah ini. Pada awal pendudukan Jepang diprakarsailah berdirinya SUDARA (Sumber
Darah Rakyat) oleh Dr. Ratulangi atas bantuan pemerintah pendudukan Jepang dan menempatkan Andi Mappanyukki sebagai Ketua dalam oraganisasi ini. Ratulangi sendiri bertindak sebagai wakil ketua sekaligus menjadi organisator yang efektif dalam SUDARA ini. Tokoh-tokoh lainnya, diantaranya; Lanto Daeng Pasewang sebagai kepala bagian umum, Mr. Tadjuddin Noor sebagai kepala bagian ekonomi, Sijaranamual dan Saelan ditunjuk sebagai biro pemuda. Hubungan Ratulangi dengan Raja Bone Andi Mappanyukki dalam SUDARA amat penting untuk memudahkan kerjasama antara kaum nasionalis Makassar yang kosmopolitan dan kaum bangsawan tradisional di kerajaan-kerajaan setempat untuk mendukung Republik dan untuk menentang kembalinya Belanda (Audrey R. Kahin, 1985: 211-212).

Dalam perjalanannya, organisasi yang dimaksudkan oleh Jepang sebagai propaganda anti Barat (Belanda) ini, ternyata diarahkan oleh tokoh-tokoh pergerakan Sulawesi Selatan ke arah penumbuhan nasionalisme dikalangan rakyat dalam mempersiapkan kemerdekaan. Terdapat tiga tokoh pergerakan lokal persatuan progressif Ken Koku Dosi Kai atau SUDARA ini yang sangat aktif menanamkan propaganda dan menggalang perjuangan rakyat baik di pelosok daerah, maupun di dalam kota Makassar sendiri, yakni; Dr. Ratulangi, Mr. Tadjuddin Noor dan Nadjamuddin Daeng Malewa (Kementerian Penerangan RI, 1953: 210).

Organisasi tersebut meluas ke seluruh daerah dalam bentuk-bentuk komitekomite perjuangan (comite van actie). Menurut Willem Ijzereef, "Nadjamuddin Daeng Malewa seorang nasionalis yang mempunyai pengaruh luas sempat bekerjasama dengan Ratulangi dan termasuk pengurus didalamnya. Tapi kerjasama itu tidaklah begitu baik. Ratulangi dan

Najamuddin, Persaingan Elit Bangsawan dengan Kelompok Terdidik pada Masa Revolusi di Sulawesi Selatan 
Tadjuddin Noor berada dalam persaingan, sedang kesetiaan Nadjamuddin diragukan" (Willem Ijzeeref, 1984). Terdapat kemungkinan, Nadjamuddin yang merasa dirinya mempunyai kemampuan dan banyak berjasa terhadap Pergerakan Nasional di Sulawesi Selatan, ternyata ditempatkan pada posisi tak berarti dalam SUDARA yang baru dibentuk oleh Ratulangi tersebut.

Nadjamuddin Daeng Malewa dan Mr. Tadjuddin Noor semakin merasa disingkirkan oleh Dr. Ratulangi setelah munculnya undangan dari pihak penguasa Angkatan laut Jepang untuk menghadiri rapat Panitia Persiapan Kemerdekaan Indonesia (PPKI) di Jakarta. Dari namanama yang diberangkatkan rupanya kedua tokoh itu tidak ada, melainkan yang diberangkatkan ke Jakarta adalah; Dr. Ratulangi, disertai oleh Andi Pangerang Petta Rani (Anak Arumpone Andi Mappanyukki), Sultan Daeng Raja dan Mr. Zainal Abidin (Ide Anak Agung Dge Agung, 1985: 49-50).

Dari susunan nama yang diberangkatkan ini, tokoh-tokoh Pergerakan nasional asal Sulawesi Selatan yang sebelumnya banyak berpengaruh terhadap tumbuhnya rasa nasionalisme di daerah ini tidak termasuk didalamnya. Tidak diikutsertakannya Nadjamuddin Daeng Malewa dalam delegasi Ratulangi itu semakin menimbulkan banyak kekecewaan dalam hati sanubari Nadjamuddin Daeng Malewa yang sangat mempengaruhi sikap politiknya dalam perkembangan politik di Sulawesi dikemudian hari (Ide Anak Agung Gde Agung, 1985: 51).

Penunjukan keempat tokoh tersebut mewakili Sulawesi Selatan ke sidang PPKI jelas semakin mengecewakan hati Nadjamuddin. Ini dapat dimengerti karena Nadjamuddin Daeng Malewa adalah putera Sulawesi Selatan yang pernah menjadi anggota Partai Politik Parindra dan sangat besar pengaruhnya di dalam serikat-serikat buruh angkutan perahu. Dilihat dari sudut ini memang dapat dianggap Nadjamuddin Daeng Malewa adalah seorang tokoh Politik yang terkemuka di daerah Sulawesi Selatan (IAAGA, 1985: 50-51). Demi kemajuan ekonomi dan kemandirian Sulawesi Selatan membuat ia mempertaruhkan integritasnya di dunia pergerakan dengan memilih jalan kooperatif baik pada masa pendudukan Jepang maupun pada masa Revolusi Kemerdekaan.

Pengangkatan Ratulangi sebagai Gubernur Sulawesi oleh Ir. Soekarno setelah Proklamasi kemerdekaan 17 Agustus 1945 mengundang berbagai "pertanyaan", bukan saja Nadjamuddin yang sejak awal menjadi "seterunya". Melainkan di kalangan raja-raja dan bangsawan Sulawesi Selatan pun muncul ketegangan-ketegangan atas pengangkatan Ratulangi, tetapi berkat dukungan aktif Andi Mappanyukki, maka sebagian besar bangsawan Sulawesi Selatan kemudian turut mendukungnya melalui "Deklarasi Djongaya" 15 Oktober 1945 (IAAGA, 1985: 56).

Refleksi persaingan itu semakin jelas terlihat dari pembentukan organisasi oleh ketiga tokoh pergerakan masing-masing. Dr. Ratulangi yang lebih awal mendirikan Pusat Keselamatan Rakyat Sulawesi (PKR) tidak memberikan kedudukan "stategis" bagi Mr. Tadjuddin Noor yang sejak awal setia mendampinginya. Sedangkan Nadjamuddin Daeng Malewa sama sekali tidak masuk dalam kepengurusan itu. PKR ini kemudian dianggap sebagai badan resmi dari pemerintah Gubernur Sulawesi. Dalam waktu yang bersamaan dibentuklah Partai Nasional Indonesia (PNI) oleh Mr. Tadjuddin Noor sekaligus menjadi ketua partai itu. Sedangkan Nadjamuddin sendiri tetap berada di Partai Sarekat Selebes dan mempertahankan cirinya sebagai organisasi

Najamuddin, Persaingan Elit Bangsawan dengan Kelompok Terdidik pada Masa Revolusi di Sulawesi Selatan 
nasional yang memperjuangkan kepentingan lokal.

Konflik antara elit bangsawan dengan elit terdidik yang diwakili oleh kaum pergerakan ini, kemudian dimanfaatkan oleh Pemerintah Hindia Belanda. Nadjamuddin Daeng Malewa yang kecewa terhadap sikap Dr. Ratulangi menyatakan diri bekerjasama dengan Belanda, dan pada tanggal 11 Nopember 1945 Belanda memberikan kedudukan Handels Consulent, suatu jabatan tinggi untuk orang Indonesia pada masa itu (Lahajji Patang, 1967: 109). Konflik tersebut akhirnya banyak berpengaruh terhadap kelanjutan revolusi di Sulawesi Selatan, atau sepanjang berdirinya Negara Indonesia Timur hingga menyatakan diri bergabung dengan RI dalan negara kesatuan

\section{Penutup}

Stratifikasi sosial masyarakat BugisMakassar telah memberikan posisi istimewa terhadap kaum bangsawan sebagai elit strategis dari kelompok masyarakat lainnya dalam struktur sosial, dan sebagai pemimpin puncak dalam struktur politik atau struktur kekuasaan. Pada masa Revolusi, raja dan bangsawan telah membuktikan dirinya sebagai pemimpin dan pelindung rakyat melawan penjajahan Belanda. Ketika elit terdidik tampil dalam Pergerakan Nasional di Sulawesi Selatan bersama elit bangsawan, politik kolonial Belanda berhasil mempolarisasi keduanya menjadi bagian yang terpisah dalam bingkai konflik di awal kemerdekaan RI, dan memberikan peluang terhadap pembentukan Negara Indonesia Timur (NIT).

\section{Ucapan Terima Kasih}

Dalam kesempatan ini, penulis mengucapkan terima kasih kepada berbagai pihak yang telah membantu terlaksananya penelitian ini. Tak lupa, penulis juga menyampaikan ucapan terima kasih kepada dewan redaksi Jurnal Istoria terbitan Pendidikan Sejarah, Fakultas Ilmu Sosial, Universitas Negeri Yogyakarta atas kesempatan yang diberikan sehingga tulisan ini dapat dipublikasikan pada edisi Maret 2015.

\section{Daftar Pustaka}

Abdullah, Hamid. 1985. Manusia Bugis Makassar. Jakarta: Inti Idayu Press. .1990. Reaktualisasi Etos Budaya Manusia Bugis. Solo: CV. Ramadhani

Anak Agung Gde Agung. 1985. Dari Negara Indonesia Timur ke Negara Indonesia Serikat. Yogyakarta: Gadjah Mada Press.

Arsip Pribadi M. saleh Lahade, Makassar: Arsip Nasional Perwakilan Makassar

Barbara Sillars, Harvey. 1984. Permesta Pemberontakan Setengah Hati. (terjemahan). Jakarta: Grafiti Press: . 1989. Pemberontakan Kahar Muzakkar: Dari Tradisi Ke DI/TII. (terjemahan). Jakarta: Pustaka Utama Grafiti Press.

Gonggong, Anhar. 1992. Abdul Qahhar Mudzakkar: Dari Patriot Hingga Pemberontak. Jakarta: PT. Gramedia

Errington, Shelly. 1989. Meaning and Power a Shoutheast Asian Realm. Princeton, New Jersey: Princeton University Press

Ijzereef, Willem. 1985. 1984. De ZuidCelebes Affaire, Dieren. 
Kadir, Harun et. al. 1984. Sejarah Perjuangan Kemerdekaan Republik Indonesia di Sulawesi Selatan. Ujung Pandang: Kerjasama Bappeda TK I Sul-Sel dengan UNHAS

Kahin, Audrey R (ed.). 1990. Pergolakan Daerah Pada Awal Kemerdekaan. Jakarta: Grafiti Perss.

Kahin, George Mc.Turnan. 1995. Refleksi Pergumulan Lahirnya Republik: Nasio-nalisme dan Revolusi di Indonesia. Solo/Jakarta: Sebelas Maret Universitas press \& Pustaka Sinar Harapan.

Kementerian Penerangan RI. 1953. Propinsi Sulawesi. Makassar: Djawatan Penerangan RI Propinsi Sulawesi.

Leirissa, R.Z. 1996. PRRI-Permesta: Strategi Membangun Indonesia Tanpa Komunis. Jakarta: Grafiti Press.

Mattulada. 1975. "Latoa: Suatu Lukisan Analitis Terhadap Antropologi Politik Orang Bugis" Desertasi. Jakarta: Universitas Indonesia.

1977."Siri', Darah dan Kekuasaan Politik di Kerajaan Luwu Zaman Dahulu”. dalam Bingkisan Budaya Sulawesi Selatan. Th, 1,2. Makassar: YKSST

Paeni, Mukhlis dan Robinson, Kathryn (ed.). 1985. Politik Kekuasaan dan Kepemimpinan di Desa. Ujung
Pandang: Lembaga Penerbit: UNHAS.

dkk. 1985. Sejarah Sosial Daerah: Mobilitas Sosial Kota Makassar 1900-1950. Jakarta: Disjarahnitra Depdikbud

Pawiloy, Sarita et.al. 1981. Sejarah Pendidikan Daerah Sulawesi Selatan. Ujung Pandang:Depdikbud.

Rahim, A. Rahman. 1985. Nilai-Nilai Utama Kebudayaan Bugis. Ujung Pandang: Lembaga Penerbit UNHAS

Reid, Anthony. 1996. Revolusi Nasional Indonesia. (terjemahan). Jakarta: Sinar Harapan

Sophian, Manai. 1991. Apa yang Masih Teringat. Jakarta: Yayasan Mencerdaskan Bangsa Sulawesi Selatan

Sutherland, Heather.A. 1983. Terbentuknya Sebuah Elit Birokrasi.(terjemahan). Jakarta: Sinar Harapan

Walinono, Hasan. 1979. "Tanete: Suatu Studi Sosiologi Politik”. Disertasi. Ujung Pandang: Universitas Hasanuddin

Wetheim,W.F. 1999. Masyarakat Indonesia Dalam Transisi Sosial (terjemahan). Yogyakarta: PT. Tiara Wacana Yogya 